\title{
Pseudonimia e pseudoalofonía: as carautas onomásticas de Álvaro Cunqueiro nos seus artigos e traducións
}

\author{
Xosé-Henrique Costas ${ }^{1}$
}

Recibido: 24 de xaneiro de 2021 / Aceptado: 15 de xuño de 2021

Resumo. Ao longo de medio século de creación poética e colaboracións en prensa, Cunqueiro asinou milleiros de artigos e traducións con pseudónimos e moitas traducións poéticas con ducias de pseudoalófonos, de maneira que as máscaras onomásticas empregadas polo mindoniense sobrepasan o centenar. Neste artigo facemos unha aproximación a estoutros cunqueiros enmascarados, revelamos as súas formas e avanzamos algunhas hipóteses sobre os motivos que levaron a Cunqueiro a usar deles. Aprofundamos na espiral desta onomástica lúdica do mindoniense desvelando medio cento de poemas de alofonía fantástica ou pseudoalofonía - que poderían ser poemas orixinais de Cunqueiro-e dous pseudónimos máis empregados como supostos «axudantes de tradución ou tradutores» de poesía alemá e sueca.

Palabras chave: Cunqueiro; tradución; pseudónimos; pseudoalófonos; onomástica lúdica.

\section{[es] Pseudonimia e pseudoalofonía: las máscaras onomásticas de Álvaro Cunqueiro en sus artículos y traducciones}

Resumen. A lo largo de medio siglo de creación poética y colaboraciones en prensa, Cunqueiro firmó miles de artículos y traducciones con pseudónimos y muchas traduciones poéticas con docenas de pseudoalófonos, de manera que las máscaras onomásticas empleadas por el mindoniense sobrepasan el centenar. En este artículo hacemos una aproximación a estos otros cunqueiros enmascarados, revelamos sus formas y avanzamos algunas hipótesis sobre los motivos que llevaron a Cunqueiro a usarlos. Profundizamos en la espiral de esta onomástica lúdica del mindoniense desvelando medio centenar de poemas de alofonía fantástica o pseudoalofonía - que podrían ser poemas originales de Cunqueiro- y dos pseudónimos más empleados como supuestos «ayudantes de traducción o traductores» de poesía alemana y sueca.

Palabras clave: Cunqueiro; traducción; pseudónimos; pseudoalófonos; onomástica lúdica.

\section{[en] Pseudonymity and Pseudoallophony: the Onomastic Masks by Álvaro Cun- queiro in his Articles and Translations}

\begin{abstract}
During half a century of poetic creation and collaborations in the press, Cunqueiro signed thousands of articles and translations with pseudonyms and many poetic translations with pseudoallophones, so that the onomatic masks used by the Mindoniense exceed one hundred. In this article we approch to those other masked Cunqueiro, we reveal their shapes and advance some hypotheses about the reasons that led Cunqueiro to use them. We delve into this ludic onomastic spiral of the Mindoniense revealing half a hundred poems of fantastical alophony or pseudoalophony - which could be original poems by Cunqueiro - and two more pseudonyms used as supposed "translators assistents" of German and Swedish poetry.
\end{abstract}

Keywords: Cunqueiro; Translation; Pseudonyms; Pseudoalophones; Ludic Onomastic.

Sumario. Limiar. 1. Os pseudónimos empregados no Faro de Vigo e outras publicacións. 2. A onomástica lúdica de Cunqueiro: a pseudoalofonía ou alofonía fantástica. 3. Os “tradutores” Matias Loederer e Berit Wöxstrom, novas máscaras? 4. Ramo. 5. Referencias bibliográficas.

1 Universidade de Vigo, Departamento de Filoloxía Galega e Latina.

Correo-e: xcostas@uvigo.es; ORCID: https://orcid.org/0000-0002-9541-1835. 
Como citar: Costas, X.-H. (2021): "Pseudonimia e pseudoalofonía: as carautas onomásticas de Álvaro Cunqueiro nos seus artigos e traducións", en Madrygal. Revista de Estudios Gallegos 24, pp. 33-50, DOI: http://dx.doi. org/10.5209/madr.80232.

Uno quisiera saber chino, y árabe, y gaélico, $y$ ver en los poemas de todas las lenguas los sueños de todos los hombres

(Álvaro Cunqueiro, "Asomándose a las traducciones", en El Noticiero Universal, 30/10/1973)

\section{Limiar}

Ao longo da súa dilatada traxectoria como colaborador en medio cento de revistas e xornais, Cunqueiro asinou preto de 20.000 colaboracións (González Somovilla 2020: XX-XXVI) de máis de medio cento de maneiras diferentes empregando adoito ducias de nomes e siglas para rubricar artigos literarios e reseñas, sobre todo no Faro de Vigo entre 1958 e 1981, publicación da que chegou a ser director. Neste inxente volume de colaboracións Cunqueiro empregou medio centenar de pseudónimos, aínda que algún deles como Manuel María Seoane se puidese encadrar máis ben como heterónimo, pois foi o nome que empregou habitualmente para a meirande parte das súas traducións poéticas. Así mesmo, usou un número aínda non determinado de formas onomásticas para xogar ao que Iago Castro denominou "alofonía fantástica" e nós "pseudoalofonía", fórmula onomástica que lle serviu para publicar poemas orixinais baixo a aparencia de traducións de poetas que, ao cabo, despois de numerosas e infrutuosas averiguacións, resultaron inexistentes. Ata o de agora podemos asegurar preto duns cincuenta alófonos fantásticos, todos eles de fasquía estranxeirizante. $\mathrm{O}$ extremo da onomástica lúdica de Cunqueiro descubrímolo cando chega mesmo a inventar inexistentes tradutores que supostamente lle axudaron a anosar poetas suecos ou alemáns ao galego. Iremos debullando neste veneciano baile de máscaras para irmos desvelando os cen cunqueiros agochados tras desas carautas, algo insólito e inaudito, por hiperbólico, no sistema literario galego.

\section{Os pseudónimos empregados no Faro de Vigo e outras publicacións}

As fontes de coñecemento para sabermos se determinados nomes e siglas aparecidos no Faro de Vigo ou noutras publicacións correspondían á autoría do mindoniense foron variadas: en primeiro lugar, xa entre os anos 1985 e 1991 forámoslle facendo unha serie de consultas en persoa a D. Francisco Fernández del Riego na biblioteca da Fundación Penzol. D. Paco sempre tivo unha memoria prodixiosa e iso daquela axudáranos a certificar bastantes dos nomes ou siglas que empregara Cunqueiro como pseudónimos e xebralos dos que nos podían parecer pero non o eran. D. Paco, ademais, corroborounos que un bo quiñón de artigos e traducións sen sinatura eran do propio Cunqueiro e non doutra autoría, do propio Del Riego ou doutros ocasionais colaboradores das páxinas de "Letras" ou de "Artes y Letras" do Faro de Vigo, seccións que eles dous alimentaran semanalmente durante moitos anos, cando non debía ser nada doado encher de contidos culturais de calidade catro páxinas semanais practicamente entre eles dous.

En segundo lugar, cotexamos os nosos datos cos existentes nos estudos que había naquela altura sobre a vida e obra do autor (Armesto Faginas 1987, Fernández del Riego 1991, González Gómez 1990 e 1991) e doutros que foron aparecendo posteriormente (Castro Buerger 2005, González Somovilla 2020 etc.), que daban testemuño e certificaban a atribución a Cunqueiro duns determinados pseudónimos ou siglas correspondentes a eses pseudónimos. En terceiro lugar, en moitas colaboracións de dubidosa atribución analizamos os estilemas xornalísticos de Cunqueiro, como foron a combinación de dialectalismos, vulgarismos e arcaísmos morfolóxicos e léxicos; certas tendencias ortográficas de cada momento histórico en que escribía moi propias da súa prosa xornalística; e -por suposto- os temas, subtemas, personaxes históricos e literarios, mitos, lendas, libros etc., aos que sempre volvía o noso autor. E, en cuarto lugar, recorremos de novo á axuda de Xesús González Gómez.

No Faro de Vigo temos fichado un mínimo de 2.600 colaboracións de Cunqueiro, ás que deberiamos engadir non menos de 300 participacións máis sen asinar (sobre todo reseñas literarias, algúns artigos literarios e unhas poucas traducións poéticas) que sempre sospeitaramos seren da súa autoría e que D. Paco del Riego nos confirmara como saídas da mente e da máquina do mindoniense. Xa que logo, Cunqueiro deixou impresas nas páxinas do $F a$ ro de Vigo por volta de 3.000 colaboracións $^{2}$,

2 Nunha estimación á baixa, porque Ceferino de Blas calcula uns 2.000 artigos só da sección El Envés. 
aproximadamente a metade en castelán e outras tantas en galego, na nosa lingua sobre todo na década final da súa existencia, entre os anos 1970-1981, colaboracións estas das que 600 foron traducións ${ }^{3}$ duns 420 autores diferentes pertencentes a máis de trinta sistemas literarios diversos e corenta países. Como a nosa intención foi sempre a de buscar materiais xornalísticos de Cunqueiro en galego, comezamos a busca no Faro de Vigo a partir de 1958, pero Cunqueiro comezara a colaborar neste xornal xa en 1950, pois o seu primeiro artigo foi "Miño por medio" o 25/07/1950. O primeiro artigo en galego do que teñamos noticia foi "Tres miragres do santo patrón" o 25/07/1963.

En Cunqueiro a tradución non foi un simple exercicio ou pasatempo lingüístico pracenteiro. Foi no seu momento (e aínda o é, en calquera sistema lingüístico e literario reemerxente) unha necesidade imperiosa do sistema literario galego, e así o comprendeu o noso autor desde ben cedo. Pero, ademais, o estudo das súas traducións literarias ten moita importancia pola súa relación directa coa produción poética de Cunqueiro; é decer: afirmamos que a poesía orixinal de Cunqueiro nunca poderá ser apreixada e comprendida na súa totalidade mentres non se teñan en conta as traducións poéticas que -en paralelo- foi realizando ao longo da súa vida literaria. Queren feitos uns estudos rigorosos que nos confirmen ou desmintan se as traducións (os "anosamentos") de Cunqueiro son sempre fieis e rigorosas, se son pseudoparáfrases ou re-creacións, ou se en ocasións son xa poemas novos afastados do orixinal traducido mais xurdido a partir del etc. Afirma González Gómez (2020b):

Cunqueiro era partidario, case sempre, das versións literais, e a maioría da súas traducións son iso, literais, o que acontece é que adoitaba pór en galego poemas doutras linguas mantendo o ritmo da lingua orixinal. Cunqueiro tiña unha teoría moi clara de como debían ser as traducións de poesía e non entraba no seu pensamento entregar un novo poema a partir dun poema noutra lingua (novos poemas que non se poden confundir con paráfrases).

Temos exemplos abondos de poemas que foron publicados en dúas, tres e ata catro ocasións ao longo de varios $\operatorname{anos}^{4}$, o que nos dá unha idea de que o anosador nunca quedaba satisfeito coa tradución realizada e sempre trataba de a mellorar. E quere feito tamén un estudo a conciencia das interrelacións entre a poesía traducida e a poesía producida, as imaxes, metáforas, temas, nomes, mitos, teimas e lugares que revoan e navegan profusamente entre os poemas traducidos e os poemas orixinais compostos coetaneamente a esas traducións. Sen a compilación das traducións de poesía foránea e da análise das conexións e lugares comúns destas coa poesía cunqueiriana - nalgúns casos ben evidentes- a comprensión da obra do mindoniense sempre será parcial e incompleta. Do mesmo xeito, quere peneirada a súa produción xornalística porque nela está a orixe de moitos poemas orixinais, de moitos mitos, personaxes, temas, lugares e imaxes empregadas posteriormente nos poemas dos seus últimos vinte últimos anos, pois grazas a algúns deses artigos puidemos certificar a autoría cunqueiriana dalgúns poemas e traducións que doutro xeito permanecerían sempre en dúbida autorial.

A proliferación e exhibición de pseudónimos tivo lugar, fundamentalmente, nos artigos literarios, nas traducións poéticas e nos artigos culturais (sobre arte, lingua, historia etc.), isto é: nas súas colaboracións no suplemento de Letras ou Artes y Letras. Fronte a un Del Riego que botou man apenas dun par de pseudónimos (Salvador Lorenzana e Cosme Barreiros), Cunqueiro encheu as páxinas do Faro de Vigo con ducias de nomes diferentes. En ocasións a sinatura dun artigo ou unha tradución eran as siglas do nome completo (A.C.), do apelido (C.) ou doutro pseudónimo xa usado (A.L., L., M.M. ${ }^{a}$ S., P.M., C.X. etc.), pero na maioría dos casos as sinaturas foron de Álvaro Labrada e Manuel María Seoane, seguidas en número de frecuencias polas de Patricio Mor, Cristóbal Xordán e Xoán Berenguer, e, en casos moi concretos recorreu a unha listaxe longa de nomes, dunha trintena de nomes diferentes, os máis deles empregados en moi contadas ocasións: Al-Faris ibn Iaquim al-Galizí; Ariel García; Benito Moirón; Benito Sar; Carlos Sobrado;

3 Apenas unha vintena de traducións son de fragmentos prosísticos, o restante é todo tradución poética.

4 O poema "O meu corazón espértame" de Jules Supervielle anosouno e publicouno de maneiras diferentes ata en catro ocasións entre os anos 1974 e 1975, sempre mellorando a versión anterior. Os poemas "Mantelo" ou "Rapaza" de Ezra Pound traduciunos ata en tres ocasións entre 1974 e 1978, ao igual có poema "O encontro" de Vladimir Holan entre 1970 e 1976. E así con case trinta poemas que foron traducidos (e mellorados) insistentemente na década de 1970.

5 Claudina Jardín (20/09/1966) e do Xardín (21/05/1972) asina senllos artigos sobre Kafka. 
César Cunqueiro; Claudina do Xardín ${ }^{5}$; Daniel Berenguer; Felipe Arteaga Masma; Felipe de Amancia; Jacques\&; Manuel Bretoña; Manuel Dafonte; Marcos Novo; Marcos Tapley; Max Hastings; Patricio Mindonio; Pedro Mateo; Pedro Miranda; Pedro Seoane ou S. Seoane; ademais de trece siglas entre as que sobrancea a de S.S. coa que asinou numerosos artigos e reseñas no suplemento de Artes y Letras $^{6}$. Velaquí os pseudónimos empregados con cadansúas variantes e siglas, en caso de as teren:

Al-Faris ibn Iaquim al-Galizí

Álvaro Cunqueiro / Cunqueiro / A.C. / C.

Álvaro Labrada / Labrada / A.L. / L.

Ariel García

Benito Moirón

Benito Sar

Berit Wöxstrom

C.M.

Carlos Sobrado

César Cunqueiro

Claudina do Xardín / Claudina Jardín

Cristóbal Jordán / Cristóbal Xordán / C.X.

Daniel Berenguer / D. Berenguel / D.

Berenguer

Felipe Arteaga Masma

Felipe de Amancia

G.R.

Jacques \&

M.C.

Manuel Bretoña / M.B.

Manuel Dafonte

Manuel (María) Seoane / M. M. ${ }^{a}$ Seoane ${ }^{7}$

/ M. María Seoane / M.S.

Marcos Novo

Marcos Tapley / Mark Tapley

Matías Loederer

Max Hastings

Patricio Mindonio

Patricio Mor / Patricio Moro / P. Mor / Patricio

\& / Mor / P.M.

Pedro Mateo

Pedro Miranda

Pedro Seoane
S.L.

S. Seoane / Seoane / S.S.

V.R.S.

X.C.

Xoán Berenguer / X. Berenguer / Berenguer

Cando nunha sección habitual de Cunqueiro asinaban unhas siglas insólitas, ou un nome infrecuente que descoñeciamos e do que non achabamos referencia ningunha, procediamos a comprobar se o estilo, os estilemas, a adxectivación, os temas e subtemas, os personaxes descritos, os tópicos e os dialectalismos eran os propios de Cunqueiro, e logo consultabamos outros estudos sobre o autor. Por exemplo, na sección "Correo sin fecha" asinan varios artigos Patricio Mor, P. Mor e P.M., e nunha só ocasión só Patricio; sen dúbida, este Patricio é Mor, é Cunqueiro. Ou se na sección "A vuelta de hoja" nos aparece nunha ocasión a sinatura de Jacques \&, cando no resto dos 36 artigos desta sección asina Cunqueiro con algún dos seus pseudónimos máis coñecidos como Patricio Mindonio, S.S. etc.-, o lóxico é pensarmos que Jacques \& é Cunqueiro, como por outra banda se pode comprobar analizando o estilo inconfundible da prosa xornalística do mindoniense, e neste caso corroborado ademais no seu día polo propio Del Riego.

É por iso polo que sempre nos inclinaramos a pensar con relativa seguridade que as siglas S.L., V.R.S., X.C., M.C. ou G.R., e os nomes Max Hastings ou Claudina do Xardín fosen outras máscaras onomásticas máis do propio Cunqueiro, pseudónimos que empregara moi esporadicamente nas súas seccións habituais. Como sempre ocorría naqueles anos do século pasado, a nosa sospeita fóranos confirmada pola memoria cronística de D. Paco del Riego. En moitas seccións, cando asinaba, sempre o facía como Cunqueiro, C., Álvaro Cunqueiro ou A.C.; por exemplo na sección en que prognosticaba os resultados da liga de fútbol

Non temos certeza de que os artigos asinados por Anric Massó (7/10/1962), R.M. (28/6/1964), M. (2/6/1978), M.L. (27/11/1977) e M.V. (14/11/1980) sexan do propio Cunqueiro, nin sequera o artigo asinado pola tan estrambótica coma inexistente Marquesa de Souiller de Saint Roman (31/5/1964), nome probablemente tomado da Marquesa Anne de Romans, amante de Louis XV, dama de vida estrafalaria, libertina, novelable e tremendamente cunqueiriana. A D. Paco del Riego pouco lle soaban estes nomes cando llos consultamos, e a nós os estilemas destas colaboracións non nos semellaron claramente cunqueirianos, agás no caso do artigo asinado pola Marquesa de Souiller de Saint Roman, que ten un leve recendo a fabulación de D. Álvaro. Así e todo, dubidamos, e por iso tampouco a incluímos como pseudónimo de Cunqueiro.

7 Non podemos estar de acordo con Carvalho Calero (1981: 749) cando di que "Cunqueiro ten utilizado tamén os seudónimos AL e MMS, maiormente o primeiro para firmar textos en castelán, e o segundo, ou as súas siglas, para traducción ó galego de poesía extranxeira". Non é exactamente así. Con Manuel María Seoane (e variantes) asinaría aproximadamente dous terzos das traducións, e con Álvaro Labrada a cuarta parte delas. Pero como Álvaro Labrada si, en troques, asinou numerosos artigos, pero tanto en castelán coma en galego, empregando este pseudónimo a nosa lingua case en exclusiva ao longo da década de 1970. 


\begin{tabular}{|l|l|l|}
\hline El Envés & $1961-1981$ & Nome e 1 pseudónimo \\
\hline Correo sin fecha & $1966-1967$ & Nome e 6 pseudónimos \\
\hline A vuelta de hoja & $1967-1968$ & Nome e 9 pseudónimos \\
\hline Poemas orixinais & $1963-1980$ & Nome e 3 pseudónimos \\
\hline Artigos culturais & $1963-1981$ & Nome e 19 pseudónimos \\
\hline Traducións poéticas & $1964-1981$ & Nome e 19 pseudónimos \\
\hline Artigos literarios & $1964-1981$ & Nome e 31 pseudónimos \\
\hline Traducións prosa & $1966-1971$ & Nome e 6 pseudónimos \\
\hline Reseñas & $1967-1980$ & Nome e 7 pseudónimos \\
\hline
\end{tabular}

botando as cartas do tarot (e que semellaba máis ben unha sección de humor deportivo) "Los pronósticos", ou as seccións "Acotaciones", "Retratos y Paisajes", "Cultura y Arte", "Una ventana", "Los días" e "Pie de Foto".

Como vemos nesta relación, o noso autor empregou profusamente da pseudonimia nos artigos de cultura en xeral (pintura, viaxes, exposicións, arte, arquitectura, gastronomía, lingüística, historia etc.), nos artigos literarios e nas traducións poéticas. Autores virán detrás de nós que desde unha crítica psicanalítica estuden a fondo as razóns destes hiperbólicos desdobramentos identitarios, desta multipolar polifonía da obra cunqueirana, tema apaixonante no que non nos imos deter no presente artigo. Alén disto, nas traducións poéticas achamos un fenómeno non orixinal pero si protagonizado claramente por Cunqueiro dentro das letras galegas: o uso da alofonía fantástica ou da pseudoalofonía, é decer: a sinatura dunha tradución dun autor estranxeiro que se revela inexistente ou que é materialmente ilocalizable. Non existindo o poeta traducido, mais existindo o poema, a dúbida que xorde é acerca da autoría dese poema: non pode ser dun autor inexistente, probablemente terá que ser dun tradutor a finxir ser un simple anosador.

\section{A onomástica lúdica de Cunqueiro: a pseu- doalofonía ou alofonía fantástica}

O primeiro caso de alofonía fantástica que coñecemos de Álvaro Cunqueiro foi ben temperán: achámolo nun Caderno manuscrito de $1928^{8}$ que contén 21 (borradores de) poemas en galego e 12 en castelán inéditos datados entre os anos 1928 e 1929; é decer, cando Cunqueiro tiña 16 e 17 anos -porque os 18 facíaos o 22 de decembro de 1929. Na páxina 55 do Caderno aparece primeiramente un poema en castelán titulado "Con Ella. De las estrellas" e a seguir, tamén en castelán, outro titulado " $\mathrm{Ca}$ minos de las estrellas blancas", os dous asinados por Álvaro Cunqueiro Mora pero este último coa apostila de se tratar dunha tradución do árabe de Ahmed-Bhen-al-Fakirí. Os dous poemas son semellantes e ambos e dous van dirixidos ao grande amor de mocidade de Cunqueiro, a bonaerense de orixes mindonienses Emma Gómez Morales, musa da maioría dos poemas contidos nese Caderno. Por máis que buscamos e preguntamos por este poeta árabe facendo todo tipo de combinacións de nome e apelidos (Ahmed, Bhen-Ben-Ibn, Fakirí-Faqirí-Fakir-Faqir) non nos aparece por ningures poeta ningún ${ }^{9}$, polo que sospeitamos que este puido ser o primeiro caso de pseudoalofonía ou alofonía fantástica de Cunqueiro.

Na edición da poesía reunida de Cunqueiro dos anos 1933-1981 (Costas e Castro Buerger 2011: 265-282) foramos ousados e introduciramos un apartado dedicado aos «poemas apócrifos», aos poemas de supostos autores estranxeiros aparentemente traducidos por Cunqueiro que ao final se nos presentaran como probables poemas orixinais do mindoniense e non traducións, tal e como sempre sospeitara e escribira anos máis tarde Xesús González Gómez (2019, 2020a, 2020b e 2020c). Nese apartado inserimos trece poemas correspondentes a doce autores dos que non achabamos noticia por ningures mentres continuamos a buscar unha vintena de autores máis que tiñamos baixo sospeita.

Para chegarmos á conclusión da inexistencia destes autores, ademais de consultarmos todas as bases de datos dispoñibles, por unha banda comprobamos con contrastados especialistas en diferentes sistemas literarios a existencia ou inexistencia dos supostos poetas traducidos e, pola outra, certificamos que cada un dos poemas traducidos recendese á última poesía de Cunqueiro, de maneira que inseridos

8 Este Caderno de 1928 está depositado na Biblioteca da Fundación Penzol en Vigo, onde o consultamos no seu día, e forma parte dos fondos que doou a familia do escritor en febreiro de 2019. Pero desde setembro de 2020, por disposición da mesma familia, non é posible consultalo.

9 Nin facendo buscas na rede (onde si aparecen varias persoas chamadas Ahmed al-Faqir, pero son futbolistas, arquitectos, dentistas etc., mais ninguén relacionado coas letras) nin preguntando a especialistas da Área de Estudos Árabes e Islámicos da Universidade de Salamanca ou do Centro de Linguas e Cultura Árabe da Universidade de El Cairo, en ningún repertorio figura o nome de tal poeta nin de tal poema "árabes" anteriores a 1930. 
no medio dos que aparecen en Herba aquí ou acolá (1991), fundamentalmente na segunda parte, na das "Sombras" (mais non só), encaixasen perfectamente na liña estética e no discurso poético final de Cunqueiro: que os temas, o estilo, a adxectivación, a ortografía, os dialectalismos, os vulgarismos, as teimas etc., fosen coincidentes ou semellantes.

Deste xeito, deduciramos xa para a nosa edición de 2011 que Decio Arveanu, Eliano Ardenau, Sigurd Hallkness, Erik Triggvason, Argret Svaden, Frank Sigmunson, Knut Tellanken, Enzo Carletti da Murona, Carlo da Marjolana, Enzio Buoncompagni e Giorgio Cantalupo non eran outra cousa que nomes inventados por Cunqueiro para publicar nas páxinas do Faro de Vigo poemas orixinais como se fosen traducións ${ }^{10}$.

Non atinamos a explicar os motivos que levaron a Cunqueiro a empregar tan vizosamente este recurso da alofonía fantástica. Unicamente podemos achar unha certa explicación desta camuflaxe nos escasos poemas que tiñan unha temática social, algo inesperable na traxectoria poética de Cunqueiro, catalogado sempre de poeta "descomprometido". Quizabes poidamos pensar nalgúns casos en que o poema estaba sen rematar e, como Cunqueiro non o querería asumir como poema acabado, sen puír, "cargáballe" ese poema propio inconcluso a outro autor como unha suposta tradución. D. Paco del Riego tíñanos contado como había días en que nin el nin Cunqueiro se erguían da cadeira e do teclado para encher do xeito que que fose as sabas das catro páxinas de "(Artes y) Letras" que deberían publicar en menos de 24 horas. Estas suposicións fundadas nosas son iso: suposicións e deducións despois de o termos falado con algúns especialistas, en modo ningún son certezas absolutas.

Así e todo, isto non explica o conxunto de medio cento de poemas publicados como traducións, de poemas pseudoalofónicos, atribuídos a persoas inexistentes, como non fose a querenza do mindoniense polas multiplicación de personaxes nunha mesma escena, a comezar por el mesmo. Xa que logo, certificamos o gusto de Cunqueiro pola onomástica lúdica, polo xogo de máscaras, por unha teimosa ocultación ou enmascaramento da súa identidade. As páxinas culturais do Faro de Vigo, mantidas case exclusivamente polas colaboracións de Cunqueiro e Del Riego durante lustros, funcionaron como unha auténtica revista Nós, traendo a Galicia e en galego o mellor e máis actual da literatura universal, da pretérita e da coetánea. Cumpriron un papel prestixiador do galego inimaxinable e impagable ao anosaren o máis selecto doutros sistemas literarios e encheren así de capital simbólico o noso idioma. É posible que o (ab)uso de pseudónimos por parte de Cunqueiro fose unha estratexia para dar a impresión pública de que eran moitos os colaboradores na cultura galega, de que era moita xente a traballar pola nosa literatura, cando en realidade eran Cunqueiro, Del Riego e, de cando en vez, algúns colaboradores esporádicos máis (Plácido R. Castro, Xaime Ferreira Alemparte, Landeira Irago e poucos máis).

Do mesmo xeito, é posible que o recurso á tradución de autores doutros sistemas literarios que tampouco participaban da corrente poética socialrealista, predominante na poesía galega da década de 1970, fose unha sorte de autoxustificación da poética cunqueiriana. Cunqueiro mantívose á marxe dos cánones poéticos da súa época e por iso foi acusado de evasionista, culturalista e intimista descomprometido. Quizais Cunqueiro botase man deste recurso da alofonía fantástica ou pseudoalofonía para reforzar con fabulados apoios externos e internacionais a súa aposta pola unha estética formal e conceptual diferente da común en tempos de combate poético e político á ditadura (Castro Buerger 2004: 35, Costas 2018: 53-54). Deste xeito, facía ver que a poesía que el compuña estaba na liña doutros autores, maiores e menores, dos outros sistemas literarios do mundo,

10 O escandinavista galego José Antonio Fernández Romero escribíranos o 14 de marzo de 2003: “(...) ningún sueco se apelida Triggvason ni Sigmundson, apellidos que, en cambio, puideran ser islandeses, pero no los nombres de pila Erik y Frank. Svaden no tiene visos de ser palabra danesa. Knut pudiera ser sueco y Tellanken suena más a finés que a otra cosa. Knut Tellanken es un híbrido que nada tiene que ver con Islandia. No obstante, he dejado perplejo al agregado cultural islandés, que en su vida había oído nombre más peregrino que Knut Tellanken, y he consultado los cuatro nombres con Francisco J. Uriz, el hombre que más sabe en España de poesía nórdica. Los dos creen, como yo, que se trata de una broma de Cunqueiro que era un gran fabulador". E ese mesmo ano o romanista e profesor da Universidade de Santiago de Compostela Christian Ionescu respondeunos así ás nosas consultas sobre Decio Arveanu e Eliano Ardeanu que: "Non existe en romanés o nome Decio, en todo caso sería Deciu, nin tampouco Eliano, que sería Elian. Posto en contacto cos responsables, nin a revista Romana Literara, nin a Fundatia Culturala Româna poden certificar a existencia destes supostos poetas". 
e xustificaba e defendía así a súa poética persoal. É outra suposición.

O crítico e investigador valdeorrés Xesús González Gómez iniciou hai décadas a busca de moitos daqueles poetas traducidos por Cunqueiro que para el lle eran totalmente descoñecidos (González Gómez 2019b):

(...) busquei na rede, na Library of Congress (dos USA), no Diccionario Bompiani de Autores, no Dictionary of Irish Literature, Robert Hoogan, Editor-in-Chief, Londres, Aldwych Press, 1996, en The Reader's Encyclopedie of American Literature, Max J. Herzberg editor, N. Y., Thomas Y. Crowell Company, 1962, varias enciclopedias e antoloxías de poesía inglesa e norteamericana, antoloxías e dicionarios de poesía francesa, na Enciclopedia Larousse, nas Biblioteca Nacional de Francia e Bibloteca Real de Bélxica, así como nas hemerotecas virtuais Galiciana, Prensa Histórica, Biblioteca Nacional de España, a francesa Gallica, a Arca catalá e algunha outra, e non os encontrei por parte ningunha.

Pois, así e todo, el mesmo recoñeceu que incluíra na súa edición de Flor de diversos, de 1991 - unha deliciosa escolma de poesía universal traducida por Cunqueiro-, dous poemas de dous poetas que logo se demostraron inexistentes: "Eu mesmo, en Flor de diversos, entreguei dous destes poemas: «O vagabundo», aposto ao suposto poeta romanés Eliano Ardeanu, e «Tantos camiños busquei», do tamén inventado poeta escandinavo Frank Sigmundson... dándoos como traducións orixinais". Do mesmo xeito, nós tamén cometeramos ese erro na nosa edición de 1991, inducidos por Cunqueiro. Ao non atoparmos por ningures referencia ningunha a un poeta chamado Antonio BarTolini, supuxeramos que sería un (outro) pseudoalófono. González Gómez fíxonos ver que o nome era un erro gráfico do apelido do poeta italiano Antonio Barolini. A partir dese erro, cando tivemos dúbidas acerca do nome dun autor do que non achabamos referencias, fixemos a busca tamén como se houbese algún erro gráfico no apelido.

En paralelo á pesquisa iniciada por González Gómez, pola nosa banda, á parte de buscarmos na rede en repertorios e bases de datos sobre poesía universal e poesía de expresión inglesa, francesa, italiana, romanesa, sueca etc., estivemos en contacto con especialistas universitarios en poesía inglesa (ingleses, escoceses, norteamericanos, canadianos, sudafricanos, irlandeses e australianos); francesa (tamén con especialistas belgas, suízos, quebequeses e africanos); italianos; alemáns (tamén suízos e austríacos), xaponeses, gregos, xudeus, árabes, suecos e polacos porque non dabamos atopado referencia ningunha acerca duns cincuenta autores desas nacionalidades ou sistemas literarios que foran traducidos por Cunqueiro.

Obramos con cautela porque, ao igual que lle ocorrera a González Gómez, xa nunha ocasión erraramos ao considerarmos un autor como inexistente cando o que acontecera fora que Cunqueiro ou o Faro de Vigo transcribira incorrectamente o seu apelido. Apreciamos en moitos casos confusión de letras, fusión de apelidos, corte de apelidos, ausencia de letras, inversión dos apelidos, confusión no nome ou no apelido etc., que non sabemos se atribuír a descoido do propio Cunqueiro ou do linotipista dos obradoiros do xornal vigués. Por exemplo: a sinatura Richard Alding corresponde en realidade ao poeta Richard Aldington; a poeta alemá non é Luise Kaschnits é Luise Kaschnitz; Linsay Vachey ten un apelido con erro e os dous alterados, pois é (Nicholas) Vachel Lindsay; André de Richard é André de Richaud; Albert Le Grant é Albert Le Grand; Chao Pinguen é Chao Ming Wen; Elynor Wilie é Elinor Wylie; Adelaide Chapsey é Adelaide Crapsey; Roland Buselen é Roland Busselen; Kamo No Chanei é Kamo No Chōnei; ou Elmer Sirktonius é Elmer Diktonius. E deste xeito poderiamos seguir cunha boa parte dos poetas traducidos. Se buscamos tal e como nos aparecen os nomes dos autores nas traducións de Cunqueiro quizais non deamos localizado bastantes dos autores traducidos, por iso, cando non atopabamos un poeta, buscabámolo por nomes e apelidos existentes na realidade e próximos fonética e graficamente a como nos aparecía no xornal, e logo buscabamos o poema na súa obra, por comprobarmos se era da súa autoría.

Así e todo, en ocasións é realmente dificultoso sabermos se hai ou non hai un poeta real detrás dunha sinatura ou é un invento cunqueiriano. Por exemplo, se facemos buscas na rede para localizarmos o poeta Clarence S. Marshall, con ese nome aparécennos cantantes, dentistas, policías e de todo; se procuramos como "Marshall poet" sáennos sete poetas distintos apelidados Marshall, pero ningún é o buscado Clarence nin ningún dos sete ten ningún poema titulado "After the storm", "Despois da tempestade" na suposta tradución cunqueiriana. Como Jan Van Viitt figuran varios gravadores, filólogos ou deportistas, ningún poeta ou escritor, mais facendo combinacións de apelidos reais cercanos o máis próximo formalmente é 
Van Vliet, que corresponde ao apelido do poeta flamenco Eddy Van Vliet. Son o mesmo? Non o podemos asegurar mentres non verifiquemos na obra deste autor a existencia do poema traducido. E, nalgunhas ocasións, hai apelidos que ou son inventos ou non existen: Waldsor (hai Waldner, Wasson, Windsor, Waldor, Waldorf etc., pero non Waldsor), Moellede (os máis próximos son Möller ou Moeller), Mourdell (hai Morel, Morell e Bourdelle, mais non Mourdell), Lanczinsky, Palaic O’Mahorty (sería Pádraic O'Mahony?) etc. Tamén se nos ten dado o caso de que un autor considerado en principio "descoñecido" como Malcolm Coleman é descuberto como Malcolm Cowley cinco anos máis tarde por seren os dous os autores do mesmo poema: "A flor no mar". O primeiro autor é descoñecido, pero o segundo non, polo que debemos supor que Coleman foi un erro por Cowley. Isto fainos obrar con moita prudencia por se se desen casos semellantes de erros tan rechamantes.

González Gómez (2019) acha na rede moitas persoas chamadas Stephen Allwright, Pat Paterson (ou mesmo Patterson), John Lennox etc., pero ningunha delas é poeta ou ten relación coa literatura. Mesmo atopa algúns poetas de nomes semellantes (Robert H. Pitney) que non pode asegurar que sexan os mesmos que Cunqueiro traduciu Cunqueiro (Robert Pitney) mentres non comprobe que na obra completa deses poetas existe o poema traducido por Cunqueiro. Nós temos achado ata nove poetas (escoceses, canadianos, ingleses e irlandeses) apelidados Ramsey, pero ningún é Oddie Ramsey; atopamos un poeta inglés do XVII chamado John Milton, pero ningún chamado John Hahne-Milton, con esa mestura de apelidos reais alemán e inglés.

Con todo este tipo de cautelas, están «baixo sospeita» de alofonía fantástica ou pseudoalofonía medio cento de (supostos) poetas traducidos por Cunqueiro e que responden aos -por agora e tras intensas pescudas - ilocalizables nomes de Antón Andreanu; Annie Crossband; Clarence S. Marshall; E. Carven-Smuts; Elias Ben Rosash; Donald Dale-France; Ellen A. Kramer; Emily Stuart-Closdel; Enrie Waldsor; Enzo Rude; Eric Von Moellede; Ernie O'Berendy; Harold M. Saville; Harry Price; Jacques Ploavel; James Kalogo; Jan Van Viitt; John S.
Lennox; John Hanne-Milton; John Stephan O' Toole; Oddie Ramsay; Palaic O'Mahorty; Paola Simonelli; Pat Paterson; Patrick Hill; Paul Krinaios; Phyllis Mac Calvert; Piera Germani; Pierre Mourdell; Piotr Lanzcinsky; Robert Pitney; Stephen Allwraight e Vittoria Merlino ${ }^{11}$.

Por todo isto, non podemos afirmar (aínda) categoricamente que todos estes sexan poetas inventados por Cunqueiro, como si o foron doce dos trece alófonos fantásticos engadidos no volume de poesía compilada de 2011 (Costas e Castro Buerger 2011). Decemos unicamente que, despois de anos de busca en todo tipo de repertorios e de consultas cos máis diversos especialistas, non achamos por ningures referencia ningunha a poetas contemporáneos ou de tempos xa idos que tivesen nomes semellantes. Dito en palabras de González Gómez (2019):

Pode ser que sexan poetas «apócrifos», mais tamén son necesarias outras liñas de investigación para saber se estes poetas existiron ou son, en realidade, poetas «apócrifos», é dicir, as composicións son en realidade do mindoniense, que inventou estes poetas e compuxo estes poemas asinados por eles.

Temos consultado mesmo con agregados culturais de embaixadas; temos solicitado axuda e consello de críticos e profesores de literatura en diversas linguas e o resultado foi sempre o mesmo: descoñecen a existencia de poetas ou escritores chamados Annie Crossband, Vittoria Merlino, Pat Paterson, Patrick Hill ou calquera dos trinta e oito referidos anteriormente, nomes todos eles que non figuran -como tales poetas- en ningunha base de datos, e hoxe é difícil que algo se lle escape á rede. A pregunta que nos xorde agora é: se este medio cento de nomes se confirmasen inexistentes, como confirmamos xa nós xa unha ducia, poderiamos considerar estes "poemas traducidos" como "poemas orixinais" de Cunqueiro? Probablemente, pero para iso deberiamos verificar tamén que lingüística e poeticamente estean no ronsel da sensibilidade lírica e da estética poética de Cunqueiro, ou polo menos do último Cunqueiro, do das "Sombras" de Herba aqui e acolá. Non os deberiamos introducir como "orixinais atopados" senón clasificalos e incluílos cautelarmente nese monllo de poemas que Castro denominou de alofonía fantástica e

11 Con motivo do XL cabodano de Cunqueiro, a Universidade de Vigo vai editar unha escolma de poesía anosada (Costas 2021) que non é senón unha compilación da poesía apócrifa en galego do mindoniense. 
nós de pseudoalofonía.

A propósito da suposta poetisa Phyllis Mac Calvert escribiu González Gómez en Biosbardia un excelente ${ }^{12}$ artigo ("Cunqueiro e o misterio Mc Calvert"), demostrando como Cunqueiro citara desde 1959 ducias de veces en ducias de artigos (en La Noche, El Progreso, Sábado Gráfico, Faro de Vigo etc.) a suposta poetisa norteamericana Phyllis (ou Phillips) Mac Calvert, da que mesmo traduciu no Faro de Vigo cinco poemas e que, ao final, resultou inexistente. Porén, localizou González Gómez unha poetisa ultracatólica norteamericana chamada Phyllis Mc Ginley que ten poemas con certas semellanzas con algúns dos de Mac Calvert traducidos por Cunqueiro. Isto di o investigador valdeorrés (González Gómez 2019b):

(...) os poemas que traduce desta poeta o escritor galego, son poemas en verdade "traducidos" ou son "apócrifos" de Cunqueiro? (...) En principio, cando menos os tres primeiros poemas que traduce poden ser non orixinais seus, senón poemas traducidos, mais de quen: de Phyllis Mc Ginley? Sobre ideas de poemas de Phyllis Mc Ginley Cunqueiro argalla novos poemas?

A resposta ou hipótese delíñaa el mesmo a partir dun dato crucial: Mc Ginley colaborou coa revista norteamericana Selecciones del Reader's Digest e, probablemente, nesta revista acharía Cunqueiro poemas ou escritos da norteamericana. O que é inexplicable é que lle mudase o apelido insistentemente, sempre, o cal xa non é lapso ningún. A única maneira de comprobarmos se Cunqueiro bebeu nesta publicación dos poemas desta autora é facendo un peneirado dos números desta revista publicados en España nas décadas de 1950 e 1960. Continúa preguntándose González Gómez (2019a):

(...) por que Cunqueiro lle apón o nome de Phyllis (ou Felipe ou Phillips) Mac Calvert? Foi un lapso que mantivo durante moitos anos, polo que se podería deitar outra hipótese: a partir dunha poeta existente o escritor galego inventou outra poeta? Unha fácil resposta sería coñecer todos os poemas de Phyllis Mc Ginley e ver se se asemellan aos traducidos por Cunqueiro: é, hoxe por hoxe, a única verificación posíbel, sen, por outra parte, descartar completamente que estes catro poemas sexan, tamén, poemas apócrifos.

Como podemos deducir deste exemplo anterior, tan ben estudado por González Gómez, son varias as comprobacións que deberemos realizar antes de darmos un poema como apócrifo ou pseudoalofónico. Tamén estamos a comprobar - porque toda precaución é poucase aínda non existindo o poeta traducido puidese existir o poema e que o poema non fose doutro autor, porque por lapsus tamén prevemos a posibilidade de que puidese haber unha atribución errada dun poema a un poeta que non é o seu autor. Por exemplo o poema "Silencio" aparece publicado o 25/05/1975 como traducido de Ezra Pound e ao pé dunha foto deste poeta, cando en realidade é do autoría do poeta John Gould Fletcher, a quen llo traduce nove meses máis tarde, o 12/02/1976. Todo o hai que certificar e revisar moi ben para que este baile de máscaras non nos leve a (máis) enganos.

Xa que logo, barallamos todas as combinacións posibles en todos os repertorios e bases de datos ao noso alcance, facendo combinacións con probables erros gráficos de apelidos ou apelidos semellantes e buscando por variantes dos títulos e primeiros versos dos poemas. E só cando comprobamos por varias vías que non existe o poeta nin o poema poderemos insertar o poeta no caixón dos alófonos fantásticos ou pseudoalófonos, e o poema nos "orixinais agochados" ou poemas apócrifos de Álvaro Cunqueiro.

Temos feito tamén algúns varridos nos numerosos volumes das seleccións e coleccións de poesía universal de Plaza \& Janés dos anos 1960 e 1970, pois Cunqueiro en ocasións deixara por escrito ao pé do poema que a tradución galega fora feita sobre a tradución en castelá contida nalgún volume destas coleccións de poesía universal. Mais tampouco demos achado ningunha pista sobre estes autores. Con todo, deberemos obrar con moita cautela por se estes poetas ata agora inexistentes puidesen ser

12 Como universitarios, botamos moito de menos unha publicación específica de literatura galega, sequera virtual. O oco deixado polo Boletín galego de literatura ou o Anuario galego de literatura cóbreno hoxe blogs magníficos de militantes da cultura de noso como Biosbardia, Cadernodecrítica, Galix ou publicacións científicas como Madrygal, pero seguimos tendo saudades e arelas dunha dedicada exclusivamente á nosa literatura. E mesmo temos saudades daquela humilde revista mindoniense de cultura, Monfadal, tan ben levada pola Fundación Álvaro Cunqueiro. 
poetas menores ou de obra exigua, de dous ou tres poemas, que -en lóxica sospeita de González Gómez-, Cunqueiro puido tirar de pequenas revistas, xornais ou edicións locais aos que puido ter acceso nalgunha das súas viaxes por Europa $^{13}$ (a Dinamarca, a Inglaterra, a Francia, a Italia, a Alemaña etc). Concordamos secasí co crítico valdeorrés cando afirma (2019b):

(...) son necesarias outras liñas de investigación, e estas liñas non son outras que revisar os fondos do suplemento do vespertino parisiense $L e$ Monde ("Le Monde des libres") e no suplemento do clásico xornal da dereita francesa, $\mathrm{Le} \mathrm{Fi-}$ garo, ("Le Figaro littèraire", que até inicios da década dos 1970 era unha revista literaria semanal), sen descartarmos, evidentemente, xornais e revistas inglesas. (...) Cunqueiro, xa o avisa Armesto Faxinas na súa biografía, usaba moito "Le Monde des libres", e moitos poemas que aparecían neste suplemento, e en "Le Figaro Littéraire", foron traducidos polo mindoniense (...), polo que para confirmarmos a existencia ou non a existencia destes poemas, dunha parte importante, pensamos, destes poemas/poetas unha fonte case que imprescindíbel son estes suplementos, xa que as veces se publicaban poemas de poetas que nunca publicarían un libro autónomo.

Deste xeito, entre pseudónimos e pseudoalófonos o número de máscaras onomásticas empregadas por Álvaro Cunqueiro aproxímase ao centenar de personae -no sentido etimolóxico de máscaras- un centenar de disfraces persoais empregados na súa obra. Uns son máis ou menos evidentes, nidios e recorrentes por estaren baseados na onomástica familiar ou na toponimia nativa sentimental do mindoniense (Moirón, Seoane, Labrada, Masma, Bretoña, Miranda etc.), sobre todo moitos pseudónimos, outros xa están contrastados e confirmados por diversos autores e algúns máis como de moi probable adxudicación ao noso escritor. Facemos nosas as palabras de González Gómez (2020) cando di que "Non podemos afirmar, categoricamente, que estes poetas non existan mais tampouco, de momento, podemos desmentir que sexan «poetas apócrifos». O certo, como dixemos, é que nós non os demos encontrado (...)".

Se se chegase a confirmar plenamente que non existen tales poetas nin tales poemas traducidos, moi probablemente poderiamos albergar a esperanza de que a obra de Cunqueiro inzase en medio cento de poemas máis que se deberían ter en conta á hora elaborar unha verdadeira e completa obra poética ${ }^{14}$ por moitos desexada. Pero con un só poema que rescatemos do esquecemento, unha soa máscara

\begin{tabular}{|l|l|l|l|}
\hline Cando se fina un home & Decio Arveanu & AL & $09 / 08 / 64$ \\
\hline O cabalo no seu escano & Phillys Mac Calvert & MMS & $16 / 08 / 64$ \\
\hline Sempre unha besta axexa & John Stephan O'Toole & AL & $23 / 08 / 64$ \\
\hline Tal como veu, fuxiu & Ernie O'Berendy & MMS & $21 / 02 / 65$ \\
\hline Paseante distraído & E. Carven-Smuts & MMS & $02 / 01 / 66$ \\
\hline Galguina dos fentos & Palaic O'Mahorty & MMS & $27 / 02 / 66$ \\
\hline Pastoral & Enzo Rude & MMS & $03 / 04 / 66$ \\
\hline
\end{tabular}

13 Por exemplo, cando traduce o 24/07/1966 o poema "Terra", de Bernard Courtin, descobre que é un poema do Livre de la ressemblance. Deste libro só se chegaron a imprimir 600 exemplares en 1952 nunha editora parisina. E nunca máis se reeditou. Como chegou Cunqueiro a coñecelo catorce anos máis tarde? Probablemente por algunha reseña ou comentario nalgún dos suplementos devanditos.

14 Nestes momentos dous pofesores da Universidade de Vigo están a rematar unha edición sobre sesenta e cinco poemas novos de Álvaro Cunqueiro achados na documentación da biblioteca da Fundación Penzol de Vigo, no depósito de fondos do pai que realizou César Cunqueiro en febrero de 2019, máis algúns poemas tirados de revistas por indicación de cunqueirólogos como César Morán ou González Gómez. Entre a documentación contida na Fundación Penzol figuran moitos (borradores de) poemas manuscritos e apenas tres mecanoscritos. Sobrancea do conxunto un Caderno de 1928 onde un Cunqueiro de 16 anos esgaravella os seus primeiros versos, de corte modernista e popularista, no ronsel de Rubén Darío, Cesário Verde, Baudelaire e Noriega Varela. Independentemente da desigual calidade literaria, este conxunto de poemas rescatados sérvenos para ver como empezaba a compoñer, cales eran os seus temas iniciais, como se atrevía un adolescente cos sonetos e, o máis rechamante, para comprobarmos a existencia ata agora descoñecida dun Cunqueiro modernista adolescente anterior ao poeta vangardista e neomedievalista dos primeiros anos da década de 1930. O día que se acometa o necesario labor de compilación dunha obra poética completa, estes poemas deberíanse incorporar nese volume, co que a produción poética do mindoniense, coa engádega de novidades, rescates e alofonías fantásticas, andaría por riba das 400 composicións poéticas, cando na Obra en galego completa. I. Poesía. Teatro publicada en 1980 só hai 120 poemas. 


\begin{tabular}{|c|c|c|c|}
\hline Os dons de San Goueann de Cinc & Phyllis Mac Calvert & MMS & $08 / 05 / 66$ \\
\hline Eu quixera ter as voces & Enzo Carletti da Murona & MMS & $10 / 07 / 66$ \\
\hline Tería que haber alguén... & Erik Von Moellede & MMS & $28 / 03 / 67$ \\
\hline Ese lago que te segue & Phillys Mac Calvert & MMS & $06 / 06 / 67$ \\
\hline Soedades & Paola Simonelli & MMS & $07 / 01 / 68$ \\
\hline Remorso & Paola Simonelli & MMS & $07 / 01 / 68$ \\
\hline Ti lonxano & Piera Germani & MMS & $30 / 06 / 68$ \\
\hline $\mathrm{O}$ vagabundo & Elianu Ardeanu & MMS & $23 / 11 / 69$ \\
\hline $\mathrm{Xa}$ foi a terra & Carlo da Marjolana & MMS & $15 / 02 / 70$ \\
\hline Os tres reis & Enzio Buoncompagni & MMS & $27 / 12 / 70$ \\
\hline Os devezos do vagabundo & Peter Isaak & MMS & $27 / 05 / 71$ \\
\hline Dende aquelas fiestras & Giorgio Cantalupo & MMS & $17 / 01 / 71$ \\
\hline Amigo de meu quen é? & Robert Pitney & MMS & $17 / 10 / 71$ \\
\hline Nin a carón nin lonxe & Piotr Lanzcinsky & MMS & $14 / 11 / 71$ \\
\hline O home que se foi á tardiña & Emy Stuart-Clowdell & $\mathrm{CX}$ & $20 / 06 / 72$ \\
\hline Outro outeiro & John Hahne-Milton & MMS & $22 / 10 / 72$ \\
\hline E Tomás dou a alma & Phyllis Mac Calvert & MMS & $27 / 05 / 73$ \\
\hline Coma sempre & Donald Dale-France & MMS & $08 / 07 / 73$ \\
\hline A sombra das arbres & Anton Andreanu & MMS & $22 / 07 / 73$ \\
\hline Deloutra parte do mundo & Phillys Mac Calvert & MMS & $17 / 03 / 74$ \\
\hline Na romaría de Santa Ana & Jacques Ploavel & MMS & $01 / 12 / 74$ \\
\hline O reparto do lume & Elías Ben Rosash & $\mathrm{AL}$ & $19 / 06 / 77$ \\
\hline Asolagado na noite & Oddie Ramsay & $\mathrm{AL}$ & $09 / 10 / 77$ \\
\hline Por aquelas rosas & Vittoria Merlino & $\mathrm{AL}$ & $30 / 10 / 77$ \\
\hline ...E nembargantes... & Patrick Hill & s.a. & $09 / 03 / 78$ \\
\hline A hedra & John Lennox & s.a. & $24 / 12 / 78$ \\
\hline A viaxe & Annie Crossband & MMS & $22 / 04 / 79$ \\
\hline Despois da tempestade & Clarence S. Marshall & s.a. & $16 / 06 / 79$ \\
\hline O mastro & Harry Price & $\mathrm{AL}$ & $15 / 07 / 79$ \\
\hline A noite & Jan Van Vitt & $\mathrm{AL}$ & $10 / 02 / 80$ \\
\hline Epitafio & Jan Van Vitt & $\mathrm{AL}$ & $10 / 02 / 80$ \\
\hline Os dous homes & Pat Paterson & $\mathrm{AL}$ & $02 / 03 / 80$ \\
\hline Aquela casa & Stephen Allwrigth & $\mathrm{AL}$ & $29 / 05 / 80$ \\
\hline Nese espello roto & Enrie Waldsor & $\mathrm{AL}$ & $12 / 06 / 80$ \\
\hline O regreso & Enrie Waldsor & $\mathrm{AL}$ & $12 / 06 / 80$ \\
\hline Neste peito dun home & Harold M. Saville & $\mathrm{AL}$ & $22 / 08 / 80$ \\
\hline Todo o que noutrora & Ellen A. Kramer & $\mathrm{AL}$ & $19 / 09 / 80$ \\
\hline
\end{tabular}

alofónica que resulte ter detrás o rostro retranqueiro de Cunqueiro, xa pagaría a pena o esforzo por descubrilo. Vexamos logo os poetas e poemas de que se trata:

\section{Os "tradutores" Matias Loederer e Berit Wöxstrom, novas máscaras?}

Vimos no primeiro apartado deste traballo como Cunqueiro traduciu poesía empregando ben o seu nome (Cunqueiro, Álvaro Cunqueiro, C., A.C.), ben seis pseudónimos, que foron principalmente Manuel María Seoane (ou

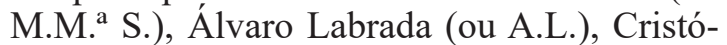
bal Xordán (ou C.X.), Patricio Mor (ou P.M.), S. S. e Xoán Berenguer. En ocasións non asinou as súas traducións ou algún poema orixinal, pero - no caso das primeiras- non é difícil sabermos se son da súa autoría porque sempre van acompañadas de reseñas asinadas por el 
sobre o autor traducido, ben na mesma folla do mesmo exemplar do xornal, ben en exemplares do día anterior ou do día posterior ou, nalgunha ocasión, do mesmo mes. Á parte de Cunqueiro, só Plácido R. Castro fixo traducións poéticas nas páxinas do Faro de Vigo, e como este último autor sempre asinaba co seu nome, non é improbable pensarmos que o $99 \%$ das traducións non asinadas fosen de Cunqueiro. Como dixemos anteriormente, hai sempre algunhas maneiras estilísticas e lingüísticas de o comprobar.

Cunqueiro entrou tamén nunha espiral lúdica e espectral coa autoría das traducións. Por exemplo, cando publicou o poema "Aquela que pousa o fuso e maila roca" (Faro de Vigo 9/1/1972) asinou co coñecido pseudónimo de Patricio Mor. O paratexto do poema di así: "Iste borrador dun poema aparecéu escrito ao marxe dun almanaque de 1911. Cheo de chataduras e de borrós, lése mal. Transcribiuno

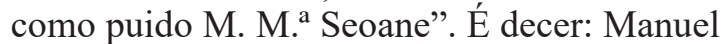
María Seoane (coñecido pseudónimo de Cunqueiro) di transcribir un poema escrito por $\mathrm{Pa}-$ tricio Mor (outro pseudónimo de Cunqueiro) nun almanaque de 1911 (ano de nacemento de Cunqueiro). Estamos perante un poema orixinal disfrazado de reprodución ou transcrición pero con moitas pistas para sabermos con certeza que é un poema orixinal de Cunqueiro. Outra volta xoga humoristicamente Cunqueiro cunha dobre superposición de máscaras de seu (Costas e Castro Buerger 2011: 21-22).

Outras veces di traducir axudado por persoas falantes nativas da lingua traducida. Por exemplo, o 31/8/1975 Cunqueiro asina a tradución do poema "Saúdo", da escritora alemá Emma Müllenhoff, e indica no paratexto ao poema que foi axudado nese labor de anosamento polo universitario alemán Matias Loederer, do que informa que é un estudante alemán que se encontra nesa época en Vigo e que acaba de traducir as sete cantigas de Martín Códax ao alemán. Non achamos por ningures rastro ningún da existencia do devandito Matías Loederer ${ }^{13}$ nin dos seus traballos. Axudaríalle a traducir ou foi un recurso que empregou Cunqueiro para lle conferir verosimilitude á súa tradución do poema de Müllenhoff?
Nós pensamos máis ben o segundo. Teñamos en conta que Cunqueiro xa viña traducindo do alemán Hölderlin desde os tempos da revista Nós, no número 130 de outubro de 1934, e volveu traducir Hölderlin nas páxinas do xornal compostelán La Noche (12/11/1949) e no Faro de Vigo (9/5/1965, 4/1/1970, 11/5/1975, 22/6/1975 etc.) e sempre traducira no $\mathrm{Fa}$ ro de Vigo autores alemáns como Rilke ( $\mathrm{Fa}$ ro de Vigo 30/4/1967, 9/3/1969, 21/12/1969, 25/2/1973 etc.), Werfel (6/4/1969), Max Jacob (30/3/1969), Heine (22/2/1970) Brecht (25/10/1970), Dürrenmatt (24/01/1971), Kashnitz (31/12/1977), Sachs (23/10/1966, 13/05/1977), Werfel (6/4/1969) etc, e sempre sen "axudante". Por que ía precisar en 1975 dun parceiro para traducir do alemán?

Podería tratarse dun caso illado de autoxustificación se non fose porque para unha ducia de poemas suecos traducidos tamén achamos outra "axudante de traducións", a suposta profesora sueca Berit Wöxstrom, que entra en escena en 1974 e parte de 1975; primeiro traduce seis poemas do sueco ao galego coa axuda de Cunqueiro e logo, en 1975, asina ela soa a tradución de dous poemas máis do sueco ao galego.

O primeiro poema sueco traducido por Cunqueiro foi no suplemento de Artes y Letras do Faro de Vigo o día 11/04/1971, cando co pseudónimo de Manuel María Seoane anosa "Que agardan os tristes corvos?" de August Strindberg. Con data de 30/7/1972, e xa co pseudónimo de Cristóbal Xordán asina a tradución dos poemas suecos «Créme a min», de Lars Forssell, e "Lisbeth, 23 anos, in memoriam", de Lars Noren. O personaxe de Berti Wöxstrom non aparece en escena ata dous meses máis tarde, o 1/9/1972, asinando este soa a tradución ao galego de dous poemas suecos de Lars Forssell, "Ulises en Itaca" e "Na casa da morte". No ano 1974 as seis traducións de poemas suecos (de Tranströmer, Lindegren, Forsell, Trunström e dous de Martinson) aparecen asinados a catro mans entre M.M.S. (Cunqueiro) e Berit Wöxtrom. En 1975 Wöxstrom asina en solitario as traducións de "A libélula" e "O contiño da estrada", do poeta finlandés en lingua sueca Elmer Diktonius o 5/1/1975 e

\footnotetext{
Aparece un Mathias Lederer, economista, pero ningún Loederer, Löderer ou Lederer poeta ou escritor.

4 Isto poderíase deber a que Cunqueiro traduciría empregando en ocasión como lingua ponte o castelán das versións que fixeron Jorge Justo Padrón (1972): La nueva poesía sueca, e Francisco J. Uriz (1974): Harry Martinson. Antología poética, na colección Selecciones de Poesía Universal da editorial barcelonesa Plaza \& Janés. Do volume de Padrón xa escollera o poema de Forsell "Créme a min" que publicou antes de aparecer en escena Wöxstrom; e
} 
de dous poemas de Harry Martinson, "Panos na néboa" e "As estrelas". Logo desta última data Wöxstrom desaparece mais Cunqueiro continuará a traducir máis poemas de autores suecos, e agora sen compaña ningunha ${ }^{14}$. Nos anos 1976, 1977, 1978 e 1979 apareceron cinco poemas máis de Harry Martinson, xunto con tres de Artur Lundkvist e dous de Goran Trunström, todos eles sen asinar pero de máis que probable atribución cunqueirana.

O día anterior á desaparición do/a «axudante», o 20/7/1975. Cunqueiro e Wöxtrom traducen a catro mans dous poemas de Harry Martinson: "Panos na néboa" e "As estrelas"15. Ao rodapé dos poemas aparece esta nota ou paratexto de Cunqueiro:

Cando lle foi concedido o Premio Nóbel de Literatura a Harry Martinson, pubricáronse nesta páxina de FARO DE VIGO dous poemas del, traducidos directamente ao galego por Berit Wöxstrom. Agora que se pubrica por primeira vez en castelán unha amplia antoloxía da poesía de Martinson -en "Selecciones de Poesía Universal", de Plaza y Janés, traducción de Francisco J. Uriz-, poden regalarse os nosos lectores coa versión galega doutros dous poemas de Martinson, feita pola señora Wöxstrom, da Universidade de Estocolmo, discípula do prof. Bertil Maler, estudioso do noso idioma e gran coñecedor da nosa terra.

Debemos precisar que cando en 1974 lle concederon o premio Nobel a Harry Martinson no Faro de Vigo non apareceron dous poemas del traducidos por Wöxstrom, senón asinados conxuntamente por Manuel María Seoane e Berit Wöxstrom, é decer: o propio Cunqueiro "esquecera" que el asinara as traducións con Wöxstrom. Debemos precisar tamén que nas bases de datos consultadas non achamos ningunha Bertil Wöxstrom poeta ou tradutora, e si en troques aparece un Bertil Weström, artista creativo visual e un Bertil Norström, actor; fixemos buscas por combinacións de apelidos próximos (Åström, Bergström, Öström) e o máis tematicamente próximo que nos saíu foi unha profesora de literatura inglesa da Universidade de Umea, Berit Åström, pero sen ningunha publicación sobre Cunqueiro nin sobre linguas ou literaturas románicas. Nunca nos apareceu ninguén chamado Berit (ou Bertil) Wöxsrom, por ningures. Si aparecen referencias a Bertil Maler, historiador e romanista sueco, á parte do famoso lingüista e poeta Bertil Malmberg. O "gran coñecedor da nosa terra" Bertil Maler existiu, era un medievalista universitario.

No artigo de Antonio Odriozola titulado "Libros de Cunqueiro" (Faro de Vigo, 27/01/1980), no apartado das seis teses de doutoramento realizadas sobre a obra de Cunqueiro dá como defendida na Universidade de Estocolmo a tese de Berit Wostrom (sic) titulada Las invenciones de Álvaro Cunqueiro, so a dirección de Bertil Maler. Desta e doutras tres teses reseñadas no artigo non achamos noticia nin cita posterior por ningures, nin da tese nin do autor, nin sequera en repositorios universitarios, polo que podemos sospeitar que, xaora, esteamos ante outras "invencións de Álvaro Cunqueiro", fabulacións que Odriozola debeu coñecer de boca do propio Cunqueiro e tomar por certas.

$\mathrm{Na}$ documentación sobre Cunqueiro que depositou o seu fillo César en febreiro de 2019 na Fundación Penzol figuran once teses de doutoramento sobre a obra do mindoniense. Estas once teses foron presentadas en oito universidades europeas e americanas diferentes entre os anos 1971 a 2013. Ningunha delas se defendeu na Universidade de Estocolmo e ningunha delas é de Berit Wöxstrom ou Wostrom. Ademais, nin a "tese" de Wöxstrom nin outras tres referenciadas no artigo de Odriozola aparezerán citadas posteriormente en libro nin artigo nin ensaio ningún sobre a obra de Cunqueiro. Xa que logo, coidamos que Antonio

moitos dos poemas suecos que traduce Cunqueiro, ben só, ben coa "inestimable axuda de Wöxstrom" figuran nalgún destes dous volumes, polo que sería innecesaria a asistencia e a existencia de Berit Wöxstrom. Para os poemas de Goran Trunström cita como fonte o volume Selected poems (1971) poemas orixinais e traducidos por C. Smith (Clark Ashton Smith).

15 No blog de literatura Estrømatolitøs (http://g-estromatolitos.blogspot.com.es/2011/11/alvaro-cunqueiro-harry-martinson.html) dise que estes tres poemas foron traducidos coa axuda de Wöxstrom, pero non é certo, só o foron os dous primeiros; o último, "O refugiado" non leva sinatura ningunha. Os dous primeiros di o autor do blog que os tomou do volume Flor de diversos. Escolma de poemas traducidos por Álvaro Cunqueiro (1991), de Xesús González Gómez.

16 Tanto Armesto (1987) como Del Riego (1991) deron exemplos de como Cunqueiro anunciaba que tiña escritos e a piques de dar ao prelo algúns títulos de libros que logo se demostraron só existentes na súa imaxinación. E verbo da súa querenza pola excelencia universitaria, nos anos 1930 escribía en cartas a amigos que xa rematara a tese 


\begin{tabular}{|c|c|c|c|}
\hline Autor & Poema & Tradutor & Data \\
\hline August Strindberg & Que agardan os tristes corvos? & M.M.S. & $11 / 04 / 1971$ \\
\hline Lars Noren & Lisbeth, 23 anos, in memoriam & C.X. & $30 / 07 / 1972$ \\
\hline Lars Forsell & Creme a min & C.X. & $30 / 07 / 1972$ \\
\hline Lars Forsell & Na casa da morte & sen asinar (s.a.) & $01 / 09 / 1972$ \\
\hline Lars Forsell & Ulises en Itaca & sen asinar (s.a.) & $01 / 09 / 1972$ \\
\hline Tomas Tranströmer & Unha noite de inverno & B.W.+ M.M.S. & $27 / 01 / 1974$ \\
\hline Erik Lindegren & A ascensión de Hamlet & B.W + M.M.S. & $10 / 02 / 1974$ \\
\hline Lars Forsell & A queixa dos amantes & B.W.+ M.M.S. & $30 / 03 / 1974$ \\
\hline Goran Trunström & Pouco despois de regresar Ulises & B.W.+ M.M.S. & $28 / 04 / 1974$ \\
\hline Harry Martinson & Lonxe do mar & B.W.+ M.M.S. & $13 / 10 / 1974$ \\
\hline Harry Martinson & Amo a madeira flotante & B.W.+ M.M.S. & $13 / 10 / 1974$ \\
\hline Elmer Dirktonius & A libélula & B.Wöxstrom & $05 / 01 / 1975$ \\
\hline Elmer Dirktonius & O conto da estrela & B.Wöxstrom & $05 / 01 / 1975$ \\
\hline Harry Martinson & Panos na néboa & B.W.+ M.M.S. & $20 / 07 / 1975$ \\
\hline Harry Martinson & As estrelas & B.W.+ M.M.S. & $20 / 07 / 1975$ \\
\hline Harry Martinson & A fonte do bosque & s.a. & $02 / 05 / 1976$ \\
\hline Harry Martinson & O consello de $\mathrm{Li} \mathrm{Ti}$ & s.a. & $02 / 05 / 1976$ \\
\hline Artur Lundkvist & Non, non é Escandinavia & s.a. & $28 / 11 / 1976$ \\
\hline Harry Martinson & Relación & s.a. & $12 / 06 / 1977$ \\
\hline Artur Lundkvist & Certo día & s.a. & $10 / 12 / 1977$ \\
\hline Harry Martinson & O fuxitivo & s.a. & $15 / 01 / 1978$ \\
\hline Goran Trunström & Realidade con cabalo & s.a. & $12 / 03 / 1978$ \\
\hline Goran Trunström & Nube & s.a. & $12 / 03 / 1978$ \\
\hline Artur Lundkvist & Son panadeiro & s.a. & $10 / 09 / 1978$ \\
\hline Harry Martinson & O refuxiado & s.a. & $30 / 09 / 1979$ \\
\hline
\end{tabular}

Odriozola debeu plasmar no artigo do Faro algunha bibliografía "fantástica" que lle debeu proporcionar o mesmo Cunqueiro ${ }^{16}$. Estes foron os suecos traducidos por Cunqueiro e estes foron os seus tradutores:

E todo isto á parte dos cinco poetas escandinavos (fundamentalmente suecos) que se demostraron inexistentes e que foron incluídos na edición de poesía de 1933-1981 (Costas e Castro Buerger 2011) dentro do apartado dos poemas apócrifos, poemas supostamente traducidos por M.M. ${ }^{a}$ S. (Manuel María Seoane) pero que deben ser orixinais de Cunqueiro, co que os poetas Sigurd Hallkness, Erik Triggvasson, Argret Svaden, Frank Sigmundson e Knut Tellanken serían novas máscaras

e estaba convidado a dar conferencias en diversas universidades europeas. No Caderno de 1928 figuran soñadas invitacións de profesoras francesas a Cunqueiro para dar aulas na Sorbonne e modelos de "cartóns de visita" ou borradores de cartas en que Cunqueiro se presenta como doutor e profesor universitario. Moito soñaba este soñador que mesmo soñaba con doutorandos a faceren teses sobre a súa obra, algunhas con nomes tan evidentes como Las invenciones de Álvaro Cunqueiro, da ensoñada Berit Wöxstrom.

17 O 20/04/1980 Cunqueiro deu a coñecer un poema titulado "Cantiga" indicando que era un orixinal en galego do poeta sueco Lasse Söderberg. Ao pé da poema explica que Söderberg compuxo "Cantiga" en galego despois de botar uns días en Galicia a dar conferencias sobre poesía sueca. González Gómez confirmounos que Söderberg mantivera certa relación afectiva con Galicia. Consultada Marta Dahlghren, esta confirmounos que o poeta sueco estivera en Galicia convidado por Carlos Casares e Kristine Berg e que o poema era orixinal del. Leva a data de 12/04/1980: Unha balada dobre/ soa en Compostela./ Recordo o teu nome/ entre noitebra/ e noitebra./ Miña amada:/ gastan as badaladas/ paseniño a pedra. 


\begin{tabular}{|l|l|l|c|}
\multicolumn{1}{c|}{ Autor } & \multicolumn{1}{c|}{ Poema } & \multicolumn{1}{c|}{ Tradutor } & \multicolumn{1}{c|}{ Data } \\
\hline Sigurd Hallkness & Erikson vólvese pra escoitar a súa... & M.M.S. & $01 / 05 / 1966$ \\
\hline Erik Triggvasson & Aínda non sei para que... & M.M.S & $21 / 06 / 1970$ \\
\hline Argret Svaden & O tempo dos probes & M.M.S & $12 / 07 / 1970$ \\
\hline Argret Svaden & A nao de Sigvar Sigvarson & M.M.S. & $12 / 07 / 1970$ \\
\hline Frank Sigmundson & Tantos camiños busquei & M.M.S & $16 / 08 / 1970$ \\
\hline Knut Tellanken & Aqueles outros ríos & M.M.S & $27 / 09 / 1970$ \\
\hline
\end{tabular}

onomásticas cunqueiranas, outro exemplo de pseudoalofonía ${ }^{17}$.

E velaquí os poetas "escandinavos" (en xeral) que Cunqueiro finxiu traducir e que se revelaron pseudoalofónicos ou apócrifos:

Se buscamos na rede Berit Wöxstrom unicamente aparece unha referencia a unha cita no libro Hamlet y el actor: en busca del personaje (Bilbao: Arteztlai, 2011), da autoría do actor e director teatral irlandés Denis Rafter. Neste volume consagrado ao estudo dos Hamlets replicados nas literaturas ibéricas dise que Cunqueiro traduciu o poema "A ascensión de Hamlet", de Eric Lindegren, o 10/2/1972, coa axuda de Vertí (sic) Wöxtrom, e Rafter dá algúns datos biográficos deste tradutor (agora é home) sueco: "Vertí Wöxtrom (Suecia 19101968), un sueco que había traducido a Eliot, Claudel, Rilke, Faulkner y Graham Greene, tradujo al gallego un poema bellísimo titulado "A ascensión de Hamlet»".

Daquela, segundo este dramaturgo irlandés, debeu existir un señor (home) chamado Vertí Wöxstrom, do que o informan que naceu en 1910, morreu en 1968 e foi tradutor da mellor literatura universal ao sueco. Agora ben, se morreu en 1968 ... como puido traducir ou axudarlle a traducir a Cunqueiro algúns poemas do sueco ao galego entre 1974 e 1975?? Estarían traducidos estes poemas ao galego antes de 1968 e non serían publicados ata 1972 e 1975 ? E, xa que logo, quen lle axudou a traducir a Cunqueiro ao galego os outros poemas de autores suecos en 1972 e no período 19761980 se xa morrera Wöxstrom?

Afortunadamente, este director teatral e hamletólogo irlandés Denis Rafter aínda vive e mora en Madrid. Puidemos localizalo e falar telefonicamente con el para lle formular estas dúbidas nosas acerca de Wöxstrom. Rafter relatounos que o volume publicado en Bilbo estaba baseado na súa tese de doutoramento defendida a finais do XX, e que non coñeceu persoalmente nin tratou Cunqueiro, malia ser un afervoado admirador d'O incerto señor Don Hamlet, príncipe de Dinamarca, polo que esta información anterior que deu sobre Wöxtrom tivo que lle chegar por outra vía diferente da transmisión directa de Cunqueiro.

Pasados máis de 25 anos desde a elaboración da súa tese de doutoramento, o traballo de investigación que deu lugar a esta publicación, Rafter non lembra quen lle proporcionou eses datos biográficos de Wöxstrom, "quizás lo tomé de la lectura de algún libro de Xesús González Gómez", manifestounos. Pero o crítico valdeorrés, co que tamén estivemos en contacto, negounos que dese dato ningún deste "tradutor" fóra do manifestado polo propio Cunqueiro ao pé dunha das traducións e que nós reproducimos máis arriba. Cando lle desvelamos a Rafter as nosas sospeitas da inexistencia de Wöxstrom a raíz das coincidencias milimétricas coa biografía do poeta e tradutor sueco Erik Lindegren, o actor e director irlandés sorriu e comentounos resignado: "vaya, Cunqueiro me ha engañado a mí también". Por medio dalguén pero a el tamén, como lle pasara a Antonio Odriozola. Agora cumpriría sabermos como difundiu Cunqueiro esa "biografía" ficticia de Berit Wöxstrom, cousa que despois de tantos anos semella empresa case imposible.

Seguíndomos outro fío da investigación sobre este tradutor ou tradutora, como non dabamos localizado ningunha referencia sobre esa persoa sueca relacionada coa tradución ou coa literatura sueca chamada Verti ou Berit Wöxstrom, a non ser esa única cita no libro

18 Marta Dahlgren, profesora de Filoloxía Inglesa en Vigo ata a súa xubilación en 2006, obtivo varios premios de tradución e está especializada na tradución de obras literarias suecas e inglesas ao galego e obras do galego ao sueco (https://gl.wikipedia.org/wiki/Marta_Dahlgren). 
de Rafter, puxerámonos en contacto coa profesora xubilada da Facultade de Filoloxía e Tradución da Universidade de Vigo, a lingüista e tradutora sueca Marta Dahlgren ${ }^{18}$, quen nos contestara moi amablemente ao cabo dun tempo o seguinte:

Fixen unhas pesquisas nos foros suecos de tradutores e non atopei nada sobre alguén apelidado Wöxstrom, nin polo apelido Woxström, que é como se escribe. Berit é nome de muller. Vertí supoño que podería ser Bertil. Moito me temo que ese tradutor é un invento de Cunqueiro.

Reparemos nun detalle: segundo lle transmitiron a Denis Rafter, e así el o verteu no seu libro, Verti Wöxstrom nacera en 1910, morrera en 1968 e traducira ao sueco obras de Eliot, Claudel, Rilke, Faulkner, Graham Greene e outros autores. Porén, ninguén nos ambientes literarios e tradutores suecos sabía nada da tradutora Wöxstrom e si en troques de Eric Lindegren, o poeta e tradutor sueco que naceu en 1910, morreu en 1968 e que curiosamente foi o único tradutor ao sueco precisamente de Eliot, Claudel, Rilke, Faulkner, Graham Greene etc. Xa que logo, temos abondos indicios para sospeitar que Cunqueiro inventou o personaxe de Verti ou Bertil ou Berit Wöxstrom e lle deu vida propia ata o extremo de o dotar de biografía e bibliografía; por unha parte fabulou unha biografía e transmitíullela a Odriozola, a Rafter e a non se sabe quen máis; pola outra creoulle unha bibliografía ao lle atribuír os méritos tradutolóxicos de Erik Lindegren, poeta ao que supostamente anosaran Cunqueiro e Wöxstrom a catro mans ao galego o poema "A ascensión de Hamlet", cando o máis probable é que fose Cunqueiro o único tradutor.

\section{Ramo}

Deberemos concluír, xa que logo, decendo que Cunqueiro inzou a súa capacidade de fabulación onomástica moito máis alá do seu medio cento de pseudónimos -maiormente galegos-, e do seu case medio cento de pseudoalófonos ou inexistentes poetas estranxeiros traducidos, aínda que sobre algúns deles teñamos posta unha interrogante ben grande por se algún día por casualidade (e de miragre) aparecese algún poeta chamado con ese nome e que aínda por riba fose xustamente o autor do poema orixinal traducido.

Cómpre estreitarmos o cerco sobre os nomes sospeitosos de "cunqueiridade" recorrendo á estratexia enunciada por Xesús González Gómez: pescudar no ronsel dos suplementos ou páxinas literarias daqueles xornais que Cunqueiro obtiña e consultaba, os xa citados de $L e$ Figaro, Le Monde e Il Corriere della Sera. Coidamos que, nun mundo coma o actual onde ata o máis mínimo detalle xa ten o seu lugar na rede, é difícil que calquera poeta, aínda que fose unicamente autor de un ou de dous poemas publicados nunha revista moi local ou no medio dunha colectánea poética, xa é frecuente e normal que o seu nome apareza nalgún repertorio ou base de datos e que, se non é posible saber del na distancia, si que é posible que o coñezan e saiban del os especialistas nesas literaturas, sexa por nacións (Escocia, Inglaterra, Irlanda, Australia, Estados Unidos, Canadá, Nova Celandia, India, Gales, Nixeria, Sudáfrica etc., para os de expresión inglesa, por exemplo) ou sexa pola lingua en que se expresou o poeta. É difícil que no mundo actual se escape algún autor, aínda que tampouco é imposible e por iso precisamente cómpre obrarmos con moita cautela á hora de decermos se un poema é apócrifo ou pseudoalofónico, pois deberemos verificar a inexistencia tanto do poeta coma do poema.

Porque -e isto é o que nos semella máis relevante- se detrás destas máscaras estivese Cunqueiro, se detrás destas falsas traducións houbese poemas orixinais, a obra poética do mindoniense tería forzosamente de ser revisada, aumentada e reestudada á luz dos novos poemas recuperados desta pseudoalofonía lúdica.

O ramo deste baile de máscaras onomásticas cunqueirianas, fóra da dobre máscara do poema "Aquela que pousa o fuso e mais a roca", está na

18 Malia que xa anteriormente tiña feitas abondas traducións de Hölderlin e doutros moitos autores do alemán ao galego. Segundo nos informara Xosé Francisco Armesto Faginas, estas traducións do alemán fixéraas Cunqueiro a través dunha lingua interposta ben coñecida por el (francés, inglés, italiano, español ou portugués), ou ben grazas á axuda de dicionarios, pois da lingua de Goethe apenas coñecía algúns rudimentos. Cunqueiro foi profesor de italiano nun instituto en Vigo en 1937 e dominaba tamén o francés e o inglés de maneira autodidacta. Sería a través destas linguas das que traduciría do alemán. Ou tamén podería ser grazas á axuda do mago Merlín, do que decía Cunqueiro que era quen en realidade o asistía coas traducións de linguas que el non coñecía ben ou descoñecía totalmente, porque sabemos que con Cunqueiro toda maxia ou miragre é posible. 
fabulación e invención destes dous «axudantes de tradución» que non foron tales, senón que se tratou doutra estratexia lúdica e práctica de Cunqueiro para lle outorgar maior credibilidade ás súas traducións de linguas - como neste caso o alemán ou o sueco- que ninguén lle ouíra falar nin lle vira escribir nunca a Cunqueiro $^{18}$. Pero eses tales tradutores non existiron e nós queremos supor que as traducións as faría

Iso si, sen dúbida, era tal a súa xenialidade poética que a maioría das traducións, fixéraas o pseudónimo ou o pseudoalófono que fose, postos eses poemas en galego por Cunqueiro, en non poucos casos superaron os orixinais e as traducións españolas, inglesas ou francesas en fermosura, eufonía e intensidade evocadora e emotiva.

\section{Referencias bibliográficas}

Armesto Faginas, Xosé Francisco (1987): Cunqueiro: unha biografía. Vigo: Xerais

Carvalho Calero, Ricardo (19813): Historia da literatura galega contemporánea. Vigo: Galaxia.

Castro Buerger, Iago (2004): "Os alófonos fantásticos. Poemas descoñecidos de Álvaro Cunqueiro", Anuario de Estudos Literarios Galegos 2004, pp. 30-39 [reeditado en Arquivo de poéticas contemporáneas na cultura, http://www.poesiagalega.org/uploads/media/castro_buerger_2004_cunqueiro.pdf].

(2005): "Unha visión sistémica das traducións de Cunqueiro no Faro de Vigo", Viceversa. Revista galega de tradución 11, pp. 23-49.

Castro Buerger, Iago e Xosé-Henrique Costas [González] (2017): No obradoiro do fabulador. Artigos en galego de Álvaro Cunqueiro no Faro de Vigo 1963-1971. Vigo: Galaxia.

(2019): No obradoiro do fabulador. Artigos en galego de Álvaro Cunqueiro no Faro de Vigo 19721981. Vigo: Galaxia.

Costas González, Xosé-Henrique (2018): “Afinidades antagónicas: Cunqueiro, anosador da Beat Generation", en Madrygal. Revista de Estudios Gallegos 21, pp. 51-70, DOI: https://doi.org/10.5209/ MADR.62593.

Costas [González], Xosé-Henrique e Iago Castro Buerger (2011): Álvaro Cunqueiro: Dona do corpo delgado. Herba aqui e acolá. Outros poemas. Poesía 1933-1981. Vigo: Galaxia.

(2013): O mundo que teño de meu. Artigos en lingua galega. Prensa e revistas 1930-1980. Vigo: Galaxia.

Costas, Xosé-Henrique (2021):

Fernández del Riego, Francisco (1991): Álvaro Cunqueiro e o seu mundo. Vigo: Ir Indo.

Fernández Rodríguez, Áurea (2016): “Álvaro Cunqueiro: una semilla en la historia de la traducción literaria gallega del siglo XX”, Transfer XI/1-2, pp. 1-25.

Forcadela, Manuel (2009): A mecánica da maxia. Ficción e ideoloxía en Álvaro Cunqueiro. Vigo: Galaxia.

Fravalo, Loïc (2004a): Álvaro Cunqueiro ici et ailleurs. Parcours littéraire et idéologique d'un auteur galicien. Tese de doutoramento inédita. Rennes: Departement d'Études Ibériques de l'Université de Haute Bretagne Rennes II / Skol-Veur Breizh Uhel Roazhon.

(2004b): "Le double choix d'Álvaro Cunqueiro. Alternance et dualité linguistique chez un écrivan galicien”, en Christian Lagarde (ed.): Écrire en situation bilingue. Perpignan: Presses Universitaires, vol. 1, pp. 131-142.

González Gómez, Xesús (1984): "Tradutor de mil poetas", en VV.AA., A Nosa Terra. O mundo de Cunqueiro, Extra 2, pp. 33-35.

(1990): Álvaro Cunqueiro, traductor. A Coruña: Fundación Caixa Galicia.

(1991): Flor de diversos. Escolma de poetas traducidos por Álvaro Cunqueiro. Vigo: Galaxia.

(2018): "Tras a pista do Cunqueiro xornalista e dos seus pseudónimos", Biosbardia 11/1/2018, biosbardia.wordpress.com/2018/01/11/tras-a-pista-do-cunqueiro-xornalista-e-dos-seus-pseudonimos/ [consulta: 17/12/2020].

_ (2019a): "Cunqueiro e o misterio Mc Calvert", Biosbardia 30/10/2019, https://biosbardia.wordpress.com/2019/10/30/cunqueiro-e-o-misterio-mc-calvert/ [consulta: 17/12/2020].

_ (2019b): “Os poetas inventados por Cunqueiro", Biosbardia 6/11/2019, https://biosbardia.wordpress.com/2019/11/06/os-poetas-inventados-por-cunqueiro/ [consulta: 17/12/2020]. 
(2019c): "No obradoiro do fabulador. Os gustos literarios de Cunqueiro", Biosbardia 27/11/2019, https://biosbardia.wordpress.com/2019/11/27/no-obradoiro-do-fabulador-os-gustos-literarios-de-cunqueiro/ [consulta: 17/12/2020].

(2020a): Poetas suecos. Traducións de Álvaro Cunqueiro, Manuel María Seoane etc. Montaxe de $X G G$ [publicación inédita distribuída en arquivo pdf].

(2020b): Antoloxía de poetas británicos, estadounidenses, canadianos, irlandeses e outros de expresión inglesa. Nova edición corrixida e aumentada por $X G G$ [publicación inédita distribuída en arquivo pdf]

- (2020c): Álvaro Cunqueiro: antoloxía de poetas italianos. Montaxe e presentación de XGG [publicación inédita distribuída en arquivo pdf]

(2020d): Antoloxía de poetas de expresión francesa: franceses, canadenses, belgas, suízos, africanos, traducidos por Álvaro Cunqueiro coa axuda de Álvaro Labrada, Manuel María Seoane, Patricio Mor, S.S. e Ariel García. Presentación e arranxo de XGG [publicación inédita distribuída en arquivo pdf].

(2020e): Poetas árabes e outros. Traduciu: Álvaro Cunqueiro. Montou: XGG. [publicación inédita distribuída en arquivo pdf].

González Somovilla, Miguel (2020): Al pasar de los años. Artículos periodísticos (1930-1981). Madrid: Fundación José Antonio de Castro.

Gregorio González, Manuel (2007): Don Álvaro, juglar sombrío. Sevilla: Fundación José Manuel Lara.

Jarazo Álvarez, Rubén (2009): La cultura de los países de habla inglesa en la obra periódica de Álvaro Cunqueiro en el Faro de Vigo (1961-1981). Tese de doutoramento inédita. A Coruña: Universidade da Coruña, Facultade de Filoloxía.

López, Teresa (2014): "Notas marxinais á poesía de Álvaro Cunqueiro", en Manuel Forcadela, Teresa López e Dolores Vilavedra (coords.): Mil e un Cunqueiros. Novas olladas para un centenario. Santiago de Compostela: Consello da Cultura Galega, pp. 465-478.

Martínez Torrón, Diego (1980): La fantasía lúdica de Álvaro Cunqueiro. Sada: Ediciós do Castro.

Nicolás, Ramón (1994): Entrevistas con Álvaro Cunqueiro. Vigo: Nigra.

Padrón, Justo Jorge (1972): La nueva poesía sueca. Barcelona: Plaza \& Janés.

Palacio Sánchez, Antón (2007): “Cunqueiro tradutor e anosador”, Viceversa. Revista galega de tradución 13, pp. 171-203.

Pazos Balado, M. Carme (1993): “Álvaro Cunqueiro traductor”, en Congreso Álvaro Cunqueiro. Santiago de Compostela: Xunta de Galicia, pp. 89-99.

Pena Sánchez, Xosé Ramón (2019): Historia da literatura galega IV. De 1936 a 1975. A longa noite. Vigo: Xerais.

Rafter, Denis (2011): Hamlet y el actor: en busca del personaje. Bilbao: Arteztlai.

Rodríguez Vega, Rexina (1997): Álvaro Cunqueiro, unha poética da recreación. Santiago: Laiovento.

Soneira Sánchez, Alba (2017): Cunqueiro tradutor e anosador de Leonard Cohen: análise comparativa de oito poemas. TFG inédito. Vigo: Universidade de Vigo, Facultade de Filoloxía e Tradución.

Tarrío Varela, Anxo (1989): Álvaro Cunqueiro ou os disfraces da melancolía. Vigo: Galaxia.

Uriz, Francisco J. (1975): Antología poética. Harry Martinson. Premio Nobel de Literatura 1974. Barcelona: Plaza \& Janés.

Vázquez Freire, Miguel (1991): Marabillas e milagres de Álvaro Cunqueiro. Vigo: Xerais.

Villanueva, Darío (1996): O realismo marabilloso de Álvaro Cunqueiro. Santiago de Compostela: Fundación Alfredo Brañas. 